\title{
PRO-POOR TOURISM FOR THE PURPOSE OF RURAL ENVIRONMENT DEVELOPMENT ${ }^{1}$
}

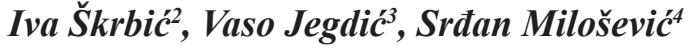

\begin{abstract}
Summary
The subject of the research in this paper is the development of entrepreneurship based on Pro-poor tourism principles in rural destinations. The aim of the research is to project development models of entrepreneurship based on Pro-poor tourism in the rural environments in Serbia. General analytical-synthetic research method has been applied, in the span of bibliographic-speculative, to empirical approach. The poverty of rural population is a heated problem in many countries, Serbia included. Developing entrepreneurship in the field of tourism stands out as one of the most efficient ways to solve this problem. Focusing on the just allocation of material and immaterial goods in a local community area includes adopting the concept of tourism and entrepreneurship development based on Pro-poor tourism. This includes the development of micro type businesses, small and family companies, the development of tourism business through diversification of products and activities traditional for the households in rural areas, and including the development principle that focuses on the interests of the poorest members of the local community. For this reason, reliance of local resources with promoting local capacities and increasing the participation level of the local community in developmental activities is the key of success of Pro-poor strategies.
\end{abstract}

Key words: Pro-poor tourism, rural development, rural destination, Serbia.

JEL: Q01, O18, Z32, I33

1 The paper is a part of the research on the project „Models of entrepreneurship development in sustainable tourism of Vojvodina“", No. 142-451-2475/2017-02, financed by the Provincial Secretariat for Science and Technological development AP Vojvodina, for year II of the project (from 2017).

2 Iva Škrbić, Ph.D., Assistant Professor, University of Educons, Faculty of Sport and Tourism, Radnička Street no. 30a, 21000 Novi Sad, Serbia, Phone +381 642014 738, E-mail: iva@tims.edu.rs

3 Vaso Jegdić, Ph.D., Associate Professor, University of Educons, Faculty of Sport and Tourism, Radnička Street no. 30a, 21000 Novi Sad, Serbia, Phone +381 635506 38, E-mail: vaso.jegdic@tims.edu.rs

4 Srđan Milošević, Ph.D., Assistant Professor, University of Educons, Faculty of Sport and Tourism, Radnička Street no. 30a, 21000 Novi Sad, Serbia, Phone +381 641800 431, E-mail: srdjan.milosevic@tims.edu.rs

EP 2018 (65) 1 (373-389) 


\section{Introduction}

The drop of the living standard and the growth of poverty in Serbia in the past two decades are, primarily, the consequences of a significant lowering of economic activity. The problem of poverty and social exclusion is made significantly more severe due to the impact of the global economic crisis. Considering that during the transition period a large number of workers were left unemployed on various bases in Serbia, as well as that the world economic crisis has additionally impacted the lack of employment possibilities of countryside population in non-agrarian activities and the cities, a growing number of countryside households started to use the available natural, housing, and agricultural resources to diversify their activities and to engage in tourism as an additional activity. The purpose of such activities was to decrease the poverty of countryside population (Ševarlić, Petrović, 2012). According to UNDP, 53.4\% of agricultural population lives below the poverty line in Serbia, and $38.7 \%$ of the countryside population lives below absolute poverty line (Živkov, 2010).

The Republic of Serbia is primarily a rural country traditionally turned to agriculture and activities characteristic of rural areas. For this reason, it is perfectly justifiable that the Tourism Development Strategy of the Republic of Serbia accentuates rural tourism as one of the strategic directions of tourism development in Serbia. As a unit of various activities that tourists can engage in in rural space, rural tourism itself is a very wide term incorporating countryside tourism, agrio-tourism, craft tourism, etno tourism, but also camps, various forms of tours, craftsmanship, cultural events, sports and recreation, hiking trails, and all forms of heritage. In other words, each tourist activity directly or indirectly connected with rural environment and space is a form of rural tourism. However, rural environments in Serbia have been facing the process of depopulation and senilization for decades, meaning the decrease in the number of inhabitants and increase of the average age of the population.

Low living standard in rural environments compared with urban environments is the basic reason of village abandonment. One of the possible ways to revitalize villages is to develop rural environments by developing entrepreneurship in the field of tourism. Being that rural environments are most often those with a low living standard and a low degree of economic development, it is necessary to focus on the population categories in greater risk of poverty. Tourism development is precisely based on Pro-poor tourism (PPT) development as a form of tourism that directs the net-profits towards the poor population, which should ensure maximum profit precisely for the most jeopardized population segments of local rural communities. Tourism development should be led by entrepreneurship development in the field of tourism and complementary areas with a primary reliance on the local resources. Entrepreneurship in the field of tourism in accordance with Pro-poor principles should strive towards higher work intellectualization based on permanent innovation, diversification of the rural economy in the direction of sustainable agriculture, but also various non-agricultural activities characteristic of the rural environments, as well as on the basis of social, cultural, ecological, and other functions of rural communities. 
Creating a development model based on Pro-poor tourism principles includes the analysis of previous scientific research studies in the relevant fields that relate to the development of entrepreneurship in rural environment for the purpose of decreasing poverty of the local population. This also includes the analysis of various case studies dealing with the creation and implementation of entrepreneurial development models, or identifying entrepreneurial development factors in comparable local communities that can serve as a model for further development of rural communities in the territory of the Republic of Serbia.

\section{Rural environments}

There is no unified definition of ruralness. Defining ruralness is a complex task and is most often seen from three different viewpoints. The first viewpoint is the population density and settlement size, the second is the purpose of the land, meaning the domination of agriculture and forestry, and the third is the traditional social structure, community identity and heritage (OECD, 1994). OECD defines rural areas as those with a population density of up to 150 inhabitants per square kilometer. According to the European Council, the term rural area describes a strip of land in the interior or on the coast, which includes smaller cities and villages, where the main part of the territory is used for economic and cultural activities of the population of that rural area (craftsmanship, industry, services), then non-urban recreation and free activities, as well as for other purposes - for example, habitation (European Parliamentary Research Service, 2012). Rural areas in Serbia are defined as a space, the main physical and geographic characteristic of which is the use of land for the production of agricultural and forestry products (Svetozarević, 2012).

The role of rural areas can be seen as needed for ensuring the existence for the part of the population which cannot be included in the official economy, then as the basis for ensuring agricultural products for the total population, as well as a territory with a wide array of ecological and bio-energetic resources (Delić,2012). Due to the importance of rural areas, active support for the development and preservation of these areas is the primary goal of the national government and international organizations. Rural development policies must primarily have the task to create a plan of rural development on a national level, combined with the support given from the local level as well, meaning that the support must be decentralized (Fotiadis, 2012).

The term rural space includes natural areas, rural environment, small settlements and villages, isolated farms with agriculture and forestry as the main economic sectors (Demonja, Baćac, 2012). Local rural resources are the foundation of rural tourism product. They are a potential for tourism that can be turned into rural touristic attractions and can be thematically profiled into an extremely diverse tourism product of rural space. Lane points out rural resources as the most significant element of rural tourism system (Lane, 1999). Some authors identify rural resources as "rural capital" (Garrod et al., 2006). Local management in local rural environments can encourage and focus local development and "create, strengthen or stabilize activities by using resources of an area in the best way possible", as Gref points out (1994). 
According to OECD criteria, rural areas in Serbia make up $85 \%$ of the total territory with almost $55 \%$ of the total population (Milić, 2011). Rural space in Serbia is one of the most socially and naturally diverse in Europe, which is why managing its development is very complex. Due to turbulent history, but also oversights in rural development policy support, it is greatly economically and socially destroyed and depressed (Đorđević Milošević, Milovanović, 2012). The basic obstacles to the development of rural areas in the territory of Serbia are the predominance of natural and semi-natural agriculture, high unemployment rate, covert unemployment and weak workforce movability, while the competitive advantages are the low price of the workforce and high-quality natural resources.

\section{Rural tourism}

Rural tourism is most frequently organized as a family business in a local community. That is the source of its strength necessary to initiate self-employment in rural areas, as this is a work intense activity. Sustainability of rural tourism is widely defined through: preservation of the local culture and the identity of the local community, villages and natural environment preservation, preservation and sustainable development of rural economy, pointing out the importance of local, regional and national authority support, but also through a balance between touristic activities in rural areas and other activities (Rikalović et al., 2012). Rural tourism can be seen as one of the reproductive mechanisms of rural economy and rural way of life (Čikić et al., 2015).

In defining the term rural tourism, some authors take as a starting point the dilemma whether the term should be rural tourism or tourism in rural areas, thus wondering whether tourism is something completely specific or whether tourism only takes place in a specific context when in rural space. Author Nina Noveli (2005) describes rural space as an important macro field, within which there are separate, specific macro niches (for example, family farms, festivals and events, craftsmanship and national artwork, gastronomic offer). Rural tourism is the most represented term including all forms of tourism in rural areas (Lane 1999; Garrod et al., 2006; Silva, Leal 2015).

Saksena et al, introduce the term "integrated rural tourism" - IRT as tourism explicitly tied to the economic, social, cultural, natural, and human structure of the location where it takes place (Saxena et al., 2007). In essence, it emphasizes the importance of territorial identity and the strategic commodification of resources and location, as well as the significance of non-local powers in initiating local activities (Petrou, et al., 2007). The goal of managing rural tourism is to encourage sustainable development of rural areas, by respecting their specificities, preservation and affirmation of authentic regional and cultural values, but also the quality of the natural environment (Škrbić et al., 2015). Rural tourism development does not only mean the development of tourism in one specific area, but further development of neighboring geographical areas as well, thus providing their tourist valorization (Petrović et al., 2017). In essence, rural tourism is based on the concept of sustainable development of local communities. The idea is to encourage rural communities to include new sources of income as additional rather than as replacement for the existing activities by developing tourism (McAreavei, McDonagh, 2010). 
Even though there are numerous studies dealing with rural tourism, there is no universal definition of this term in scientific literature. An adequate definition of rural tourism was created by "Trav Info India": "Any form of tourism that showcases the rural life, art, culture and heritage at rural locations, thereby benefiting the local community economically and socially, as well as enabling interaction between the tourists and the local community for a more enriching tourism experience can be termed as rural tourism" (www.travinfoindia.com). It is multi-functional and knowledge oriented, and is also based on the preservation of cultural heritage and tradition. It is characterized by highly personalized relations, strong individual activities and a high degree of tourist participation in the creation of the experience, as well as eco and etno framework. Successful rural tourism must be organized by local actors, as they are more familiar with the strengths and weaknesses of their destinations and are the most interested in nature preservation, preservation of cultural heritage and promotion of the wealth of their rural areas. Rural tourism is one of the alternative options of rural environment development and leads to the development of rural areas and a better territorial balance in the economic and social sense through activity diversification (Shtaltovna, 2007). It impacts economic revitalization, but also the preservation of local culture and resources, which means it has an influence on the increase of the trust of the local population (Andrić et al., 2010). Direct impact of rural tourism can be seen in product increase and ensuring secure placement of agricultural products, increased employment of the local population and the growth of their wages, increased birth rate, and indirect impact of tourism can be seen through the development of accompanying activities, such as traffic infrastructure and cultural development of the community (Đuričić, 2011).

Rural tourism in Serbia is developed in some parts of Vojvodina, Central and Western Serbia, but is still an insufficiently recognized tourism product on the national level. The basic problems slowing down the development of entrepreneurship in the field of rural tourism in Serbia are underdeveloped infrastructure, unfavorable age structure of the population, insufficient education level, lack of organization in the field of agricultural production, lack of organization in the market and lack of offices providing consulting services of various kinds. Underdeveloped brands of regional products (souvenirs), low accommodation capacities and their low quality level, bad tourism signalization, lack of management in tourism destinations, etc., should be added to this (European Economic and Social Committee, 2011).

\section{Pro-poor tourism as a development principle}

The concept of Pro-poor tourism is a relatively new one. It has been presented for the first time by the Department for International Development of the United Kingdom in 1999 (De Beer, 2011). Pro-poor tourism (PPT) is not a tourism product, nor a form of tourism, but it is a development principle that can and should be implemented in all development strategies and plans, the field of which is the development of tourism, related or complementary activities for the purpose 
of decreasing poverty of the jeopardized local communities. PPT principle is implemented into development strategies and activities for the purpose of a more just division of net positive effects of tourism.

Word Tourism Organization (UNWTO) recognizes tourism as an instrument for decreasing poverty, and has initiated a program Sustainable Tourism for Eliminating Poverty - STEP, in 2002. For the developing countries, tourism is a very important activity both in the material and in the non-material sense. The number of tourist arrivals in the most non-developed countries tripled during 1998-2008, with an average yearly growth of 13\% (International Labor Organization, 2011). However, these data do not show a complete image of tourism impact, as they do not include the impact of domestic tourism on the total gross domestic product, nor the impact of tourism on the local economy, even though some remote rural regions make a living exclusively from domestic tourism (Deloitte \& Touche, IIED, ODI, 1999).

Pro-poor tourism strategies have as their aim to create more opportunities for the poor in the tourism sector, and not to expand the total size of the sector. These strategies should be combined with the strategies of general tourism development (Bennett et al., 1999). As far as Pro-poor tourism is concerned, it can be said that it meets economic goals by ensuring permanent or temporary employment, develops entrepreneurial possibilities in the field of tourism, improves other existential conditions, such as market access, health protection, improving the participation possibilities of the poor in the decision making process (Jamieson et al., 2004). As long as the local poor population has netbenefits from tourism (creates more positive effects and income than negative effects and expenses), tourism can be classified as Pro-poor, even if the richer classes of population achieve bigger gain. Necessary cooperation between numerous interested parties on various levels is necessary for a successful development and implementation of Pro-poor tourism strategies, as well as the understanding of common and individual interests of all parties. Just as Pro-poor strategies must be complementary with the general developmental tourism strategies (higher level strategies), so Pro-poor tourism cannot succeed without a successful development of the entire tourism destination (Ashley at al., 2001).

Pro-poor tourism strategies are focused on three areas: increasing the economic gain - expanding business opportunities for the poor, increasing employment and ensuring common benefits; positive non-economic impacts - improving the quality of knowledge, skills, and abilities of the poor local population, mitigating negative impacts on the environment, and focusing the social and cultural impacts of tourism; and policy and process reform - creating strategies and plan frameworks that would further support the interests of the poor, promoting participation of the poor, and partnership of the private sector in Pro-poor tourism strategies (Ashley et al., 2001). Strategies concerning Pro-poor tourism differ from the regular tourism development strategies and must sensibly fit in with the other general strategies, which are the umbrella development documents. In the largest number of cases, tourism support is incorporated into wide strategic programs, such as the programs related to the conservation and protection, 
entrepreneurship development or infrastructural projects (Deloitte \& Touche, IIED, ODI, 1999). Pro-poor strategies strive to create a combination and optimization of three goals: more tourists, higher tourist spending, and a larger share of benefits that would actually reach the poor (Ashley, 2006).

As previously mentioned, as far as poverty is concerned, rural areas are the most jeopardized, and precisely for that reason, most Pro-poor strategies and activities are implemented in rural areas. Some authors list the advantages of agro-tourism in Propoor tourism as primary (Roe, Urquhart, 2001):

- Agro-tourism increases the possibility of a wider participation of the nonformal sector;

- Tourists reach the products on their own, meaning countryside households, and therefore, the poor population does not have travel expenses and distribution expenses;

- Agro-tourism is based on natural resources and local culture. These resources the poor do have, even if they do not have the financial means;

- Agro-tourism can be more work intense than production;

- Compared with other sectors, a larger part of the benefits is focused towards the female population.

Meyer (2007) sees the sector of accommodation services as leading in the field of Pro-poor tourism. He divides this sector into two wholes based on the activities key and secondary. The key activities create formal employment through basic and complementary tourism activities. Secondary activities include extracting activities such as laundry washing, entertainment, etc. Within the tourism economy, the nonformal sector provides significant possibilities that could be used by even the poorest population and women to gain net-benefits (Deloitte \& Touche, IIED, ODI, 1999). Strengthening of the non-formal sector increases the possibility of engagement in more occasional or temporary jobs, which leads to diversification of income sources, which in turn significantly decreases the risk of poverty in rural population. Apart from the accommodation services and agriculture, craftsmanship, art, construction, and many other types of services can be implemented into Pro-poor tourism strategies and can significantly contribute to better life quality of the poor rural population by increasing employment, increasing income, preserving the local tradition, culture, values, etc.

\section{Methodology and data sources}

The aim of this research is to discuss an approach that would improve the implementation of entrepreneurship within the framework of Pro-poor tourism in the rural communities in Serbia. The research employs analytic-synthetic, bibliographic-speculative and empirical methods. General analytical-synthetic research method is used in the paper, spanning from the bibliographic-speculative to empirical approach, with the application of document content analysis technique. Case studies, scientific papers, implemented projects, and reports and recommendations of international organizations have been used 
as data sources necessary for the analysis. Research results indicate possible guidelines and models for further development of entrepreneurship in tourism in rural communities.

\section{Case studies}

\section{European Centre for Eco Agro Tourism - ECEAT CZ}

The experiences of the Czech Republic (Holland et al., 2003) can be very significant for the application of Pro-poor tourism strategies in Serbia, due to the reason that the Czech Republic is also a former communist country that has faced problems related to transition and privatization. In the Czech Republic, as well as in Serbia, during the communist period, private property and entrepreneurship were not present in a bigger volume and all economic activities of the country took place through a central-plan system. As far as the development level of tourism in rural areas and resource basis for further touristic development are concerned, the Czech Republic, similarly to Serbia, was at the time at the very beginning of development, without any tourism products, and in possession of only pure, unpolluted environment in the observed areas, without any capital for further investments in entrepreneurship, as well as without any will or desire for partnership and joint activity.

The application of Pro-poor tourism in rural areas of the Czech Republic occurred in various phases. The carrier of this program was a non-profit non-government organization ECEAT CZ (European Center for Eco Agro Tourism). The first phase took place in the period of 1995 to 1998. The goal of this phase was to build infrastructure capacities, to perfect the knowledge and the skills in the field of tourism business, and to create a tourism product. The first step included the analysis of the needs, strengths and weaknesses of all identified interest parties from the government, private and non-government sector from the territory of the observed five regions, as well as to build institutional capacities. Using seminars, training and education, they tried to raise awareness of the common goals and interests which arise with developing rural tourism. They also worked on strengthening mutual cooperation for the purpose of a successful implementation of the long term development strategy. Developing skills and knowledge necessary to be included in the tourism offer was the next step, where the training focused on the local inhabitants of the observed municipalities. Through education, seminars and printed material, they tried to develop awareness of the importance of tourism development for the local communities and individuals, then to raise the participation level of the local population in decision making, and they worked on standardization and quality of tourism products and services, as well as on preserving the environment in accordance with sustainability principle. The idea of developing capabilities was seen as a long-term network-type activity.

The second phase occurred in the period of 1998 to 2000, and it dealt with the development of tourism routes based on tradition and heritage. The process included four key steps:

- building partnerships,

- identifying tourism products of the route, 
- training of the interested parties and strategy development, and

- route marketing.

The basic problem occurring in this period was inadequate political and financial support. Institutional frameworks were a problem due to political instability and frequent staff changes. Despite the problems, ECEAT CZ decided to continue with the activities, and in expanded volume. Apart from creating the tourism products, the primary goals, among others, were to fully utilize the resource capacities, as well as "alternative" vacations trend, include new municipalities in rural tourism, include additional or complementary elements of the tourism product, expand the offer and increase tourist spending in the observed areas. Further continuation of activities transcends national frameworks and it becomes included in the EU PHARE program activities, the goal of which is to regenerate the rural economies of Central, Eastern, and Southeastern Europe that used to be under the communist regime. The example of the Czech Republic depicts a well planed multi-phase approach to the creation and implementation of Pro-poor tourism strategies from all levels of activity for the purpose of rural development and decreasing poverty. The experiences of countries with similar resource and political frameworks are a valuable instrument and guide for the development and the application of Pro-poor tourism strategies in Serbia.

\section{Artisanal handicrafts - case study from Nepal, Laos and Indonesia}

The study "Tourism, the poor, and other stakeholders: Experience from Asia" (Overseas Development Institute - ODI, 2000, according to: Epler-Wood, 2002), states that the income from sales of handicrafts in Nepal participated with nearly $15 \%$ in the total tourism income in 1990. In a specific case, government authority and private tourism operators gave their support to the manufacturers of handicrafts in the Nepal region of Kullu, which developed an advanced production of souvenirs, with scarfs, hats, gloves, etc., which are now important export articles. On the other hand, numerous examples indicate that women from the local community, as well as in the $\mathrm{Sa} \mathrm{Pa}$ area in Laos, create first class original artwork with decorative embroidery and similar, just for those to be sold for extremely low prices, in the same range as imitation products, in order to make money that their families depend on. In many cases, the local population has excellent products suitable for sale, but they lack marketing skills and partnership relations with tourism operators. In this situation, they are forced to sell those unique products as cheap imitations. According to the aforementioned study, this problem could be solved if the agencies would intervene with the promotion, for example, by organizing exhibitions that would create a more favorable position for all the handicraft manufacturers. In Irian Jaya in Indonesia, they organize yearly artwork exhibitions that would prevent this problem and create significant profit for the local artisans - carpenters.

\section{The government and the local population on the same task-Sikkim area in India}

Agro-tourism based on natural resources and local culture initiated the development of a small poor country - Sikkim, in India. This mountain area in the north of India is famous 
for its inaccessible terrain, underdeveloped industry and lack of infrastructure. The problems that had limited the development of this area for centuries have been turned into advantages, by placing topographic diversity, pleasant climate, rich bio-diversity and cultural heritage as attraction factors for the tourists. The government is conducing a project of sustainable tourism based on ecological, economic and socio-cultural aspects of tourism development, with the intention to establish a suitable balance between these three dimensions in order to guarantee its long-term sustainability. The project was in accordance with the Government decision from the year 2003, according to which this area should completely turn to organic agricultural production and become an area with sustainable organic product, as was achieved. Tourism development generated both direct and indirect employment for the local population by developing countryside, eco, and agro tourism, with favoritism of the local population to use local resources and local work force in the highest possible measure for the purpose of generating as significant benefits as possible for the local population. Intense tourism promotion by the state lead to a fourteenfold increase in profit in the period the period of 25 years (Sattar, 2014). This is a good example how the government incentives aimed at using the available local products and active participation of the local population create multiple benefits from tourism, primarily for the poor rural community.

\section{Implementation factors of Pro-poor tourism strategies - empirical experiences analysis}

In "Global Entrepreneurship Monitor 2013" report, identifying the factors of entrepreneurial development as a whole has been done based on three groups of sources. The first source consists of the previous scientific research, the second source is examining the opinions and thoughts of national experts, while the third group of information is given by the population through questionnaires (Amorós, Bosma, 2013).

In previous research studies a wide range of factors have been identified impacting Propoor tourism project implementation. Content analysis is a practical technique used to identify those factors. This includes comparison of the existing knowledge regarding strategies and activities of Pro-poor tourism and the experiences from project management, tourism planning and previous research development (Tolkach et al., 2012).

Taking into consideration the extremely high number of scientific papers, case studies, reports, and recommendations dealing with the problem of principles and strategies of Pro-poor tourism, and for the purpose of reaching a systematic, wide ranging and relevant overview of influencing factors, a table overview has been created (Table 1) of the most relevant factors of entrepreneurship development in accordance with Propoor tourism principles in relation to each document included in this analysis (scientific papers, case studies, reports, and recommendations). Each of the analyzed documents is available to the public, and with the help of bibliographic data, original document can be accessed. 
Considering the high number of documents created in various periods, by various authors, for various purposes and based on different methodologies, complete standardization of observation and analysis was not possible, but the authors strove towards achieving as high degree of equable exit information as possible for the purpose of further analyticsynthetic observation and elaboration, as well as to achieve comparison of the results gained. For this reason, all identified factors/groups have been observed in their neutral form (e.g. group of financial factors), even though in individual original documents they would be presented in the positive (induction) form (e.g. available subsidized loans) or in the negative (limiting) form (e.g. lack of favorable sources of finance).

Table 1. An overview of entrepreneurship development factors based on the documents analyzed

\begin{tabular}{|l|l|l|l|l|l|l|l|}
\hline & & & & & \\
\\
Document/Author
\end{tabular}




\begin{tabular}{|c|c|c|c|c|c|c|c|c|}
\hline Document/Author & 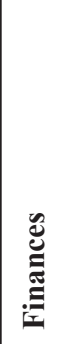 & 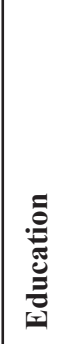 & 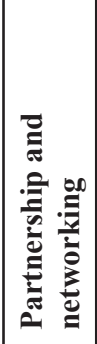 & 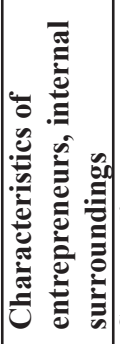 & 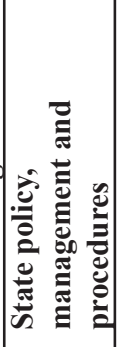 & 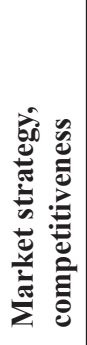 & : & 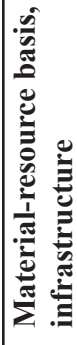 \\
\hline $\begin{array}{l}\text { The opinion of European economic and social } \\
\text { committee regarding rural development and } \\
\text { employment in the countries of Western Balcans } \\
\text { (European Economic and Social Committee, } \\
\text { 2011). }\end{array}$ & & + & + & & + & & + & + \\
\hline $\begin{array}{l}\text { The study of sustainable tourism and } \\
\text { poverty elimination, Report to the Sector for } \\
\text { international development (Bennett, Roe, } \\
\text { Ashley, 1999) }\end{array}$ & + & + & + & + & + & + & + & + \\
\hline $\begin{array}{l}\text { Pro-poor Tourism: A Vehicle for Development } \\
\text { in Trinidad \& Tobago (Lewis \& Brown, 2007) }\end{array}$ & + & + & + & & + & + & + & + \\
\hline $\begin{array}{l}\text { Diversifying the product and expanding } \\
\text { the benefits in rural Uganda and the Czech } \\
\text { Republic (Holland, Burian, Dixey, 2003) }\end{array}$ & + & + & + & & + & + & + & \\
\hline $\begin{array}{l}\text { Entrepreneurship as an economic force in rural } \\
\text { development (Sherief, 2008) }\end{array}$ & + & + & & & & + & & + \\
\hline $\begin{array}{l}\text { Pro-poor Tourism Development in Viengxay, } \\
\text { Laos: Current State and Future Prospects } \\
\text { (Suntikul, Bauer, Song, 2009) }\end{array}$ & + & + & & + & + & & + & \\
\hline $\begin{array}{l}\text { Pro-poor Tourism Strategies: Making Tourism } \\
\text { Work For The Poor (Ashley, Roe, Goodwin, } \\
\text { 2001) }\end{array}$ & + & + & + & & + & + & & + \\
\hline $\begin{array}{l}\text { Small Business Development and Poverty } \\
\text { Allerviation in Alexandra South Africa } \\
\text { (Agupusi, 2007) }\end{array}$ & + & + & + & & + & & & + \\
\hline $\begin{array}{l}\text { Global Entrepreneurship Monitor } 2013 \\
\text { Global Report Fifteen Years of Assessing } \\
\text { Entrepreneurship Across the Globe (Amorós, } \\
\text { Bosma, 2013) }\end{array}$ & + & & + & + & + & + & + & + \\
\hline $\begin{array}{l}\text { How Can Governments Boost the Local } \\
\text { Economic Impacts of Tourism? Options and } \\
\text { Tools (Ashley, 2006) }\end{array}$ & + & + & + & & + & + & & + \\
\hline $\begin{array}{l}\text { Pro-poor Tourism: Putting Poverty at The } \\
\text { Heart of the Tourism Agenda (Ashley, Boyd, } \\
\text { Goodwin, 2000) }\end{array}$ & + & + & + & & + & + & & + \\
\hline $\begin{array}{l}\text { Rural tourism development: a viable formula } \\
\text { for poverty alleviation in Bergville (Mthembu, } \\
\text { Rural tourism development: a viable formula } \\
\text { for poverty alleviation in Bergville, 2012) }\end{array}$ & + & + & + & & & + & + & + \\
\hline $\begin{array}{l}\text { Community Tourism Entrepreneurship for } \\
\text { Sustainable Tourism Management in Southern } \\
\text { Africa: Lessons from Zimbabwe (Chiutsi, } \\
\text { Mudzengi, 2012) }\end{array}$ & + & + & + & & & + & & \\
\hline $\begin{array}{l}\text { Pro-poor tourism as a means of Sustainable } \\
\text { Development in the Uctubamba Valley, } \\
\text { Northern Peru (Wood, 2005) }\end{array}$ & + & + & + & + & + & + & + & + \\
\hline
\end{tabular}




\begin{tabular}{|c|c|c|c|c|c|c|c|c|}
\hline Document/Author & 异 & : & 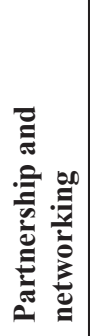 & 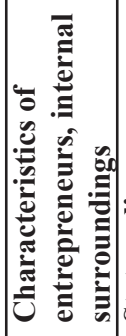 & 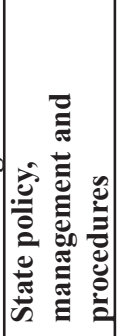 & 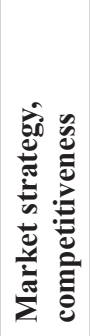 & 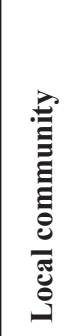 & 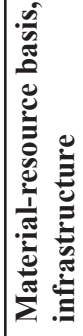 \\
\hline $\begin{array}{l}\text { Contribution of Tourism to Poverty Alleviation } \\
\text { Pro-poor Tourism and the Challenge of } \\
\text { Measuring Impacts } \\
\text { (Jamieson, Goodwin, Edmunds, 2004) }\end{array}$ & + & + & & & + & + & & + \\
\hline $\begin{array}{l}\text { Limiting factors of the local economic } \\
\text { development in the Republic of Serbia } \\
\text { (Maksimović, 2011) }\end{array}$ & & + & + & + & + & & + & + \\
\hline $\begin{array}{l}\text { The participation percentage of a group of } \\
\text { factors in the documents analyzed }\end{array}$ & $88 \%$ & $88 \%$ & $84 \%$ & $32 \%$ & $88 \%$ & $72 \%$ & $60 \%$ & $84 \%$ \\
\hline
\end{tabular}

The analysis indicates that, in previous research regarding entrepreneurial factors in rural tourism, the most presented factors were those related to finance, education, as well as state policies and procedures. On the other hand, the least represented factors were those related to the local community, as well as the characteristics of entrepreneurs and internal surroundings.

This table overview provides the starting basis for further empirical research, for example, examining the level of significance of the defined entrepreneurial development factors in tourism in rural, local communities in Serbia by determining the opinions and stances of the interested parties. In this way, it is possible to define a wider list of individual factors with different impact on the development of rural entrepreneurship for each group of factors, which make up the specificity of each local environment. So, for example, within a group of factors related to finances it is possible to identify the following individual factors: non-refundable means used for initiating the entrepreneurial activity; selective financial benefits (decreased tax rate, etc.); subsidized loans by the state; local grant funds; means from donations and foreign funds for the development of specific entrepreneurial activities (youth employment, women employment, revitalization of old craftsmanship and similar) etc.

\section{Conclusion}

Focusing on the fair and just division of the material and immaterial benefits in the area of a local community means the adoption of tourism development and entrepreneurship based on Pro-poor tourism principles, where the focus is placed on achieving netbenefits for the poorest members of the community. For this reason, relying on local resources by improving local capacities and increasing the participation level of the local population in developmental strategies is the key to success of Pro-poor strategies. 
The analysis of previous scientific and expert research studies, as well as practical experiences, indicate a certain level of factors that have a strong influence on the development of entrepreneurship in rural tourism based on Pro-poor principles. Eight factor groups have been identified with a large number of individual factors. It is of great importance to determine the significance level, or the influence and importance of individual factors in a specific rural environment.

During the analysis of the empirical application of various Pro-poor tourism strategies in the world (through materials available in the form of scientific papers, case studies, reports and recommendations), the problem of data and information systematization occurred due to various approaches to the research subject. Furthermore, the observation level in various studies was different (from macro level, to the regional level). By relying on the available theory, a framework concept of systematization of various factors according to the defined groups has been created.

\section{References}

1. Amorós, J.E., Bosma, N. (2013). Global Entrepreneurship Monitor 2013 Global Report Fifteen Years of Assessing Entrepreneurship Across the Globe. Global Entrepreneurship Research Association, Desarrollo.

2. Andrić, N., Tomić, D., Tomić, G. (2010). Status and Perspectives of Development of Rural Tourism in the Autonomous Province of Vojvodina. 118th EAAE SeminarRural development: governance, policy design and delivery, Ljubljana, Slovenija, pp. 611-621.

3. Ashley, C. (2006). How Can Governments Boost the Local Economic Impacts of Tourism? SNV East \& Southern Africa, Nairobi, Kenya.

4. Ashley, C., Roe, D., Goodwin, H. (2001). Pro-Poor Tourism Strategies: Making Tourism Work For The Poor, A review of experience, Pro-Poor Tourism Report No. 1. Overseas Development Institute, London.

5. Bennett, O., Roe, D., Ashley, C. (1999). Sustainable tourism and poverty elimination study: a report to the department for international development. Podgorica: United Nations Development programme, office in Podgorica.

6. Čikić, J., Petrović, M., Đurđev, B. (2015). Diffusion of knowledge and rural tourism development - Example of Vojvodina. Economics of Agriculture, 62(1), pg. 123136, Institute of Agricultural economics, Belgrade, Serbia.

7. De Beer, A., De Beer, F. (2011). Reflections on pro-poor tourism in South Africa: challenges of poverty and policy in the search for a way forward. Journal of Contemporary Management, 8, pp.591-606, University of Pretoria, South Africa.

8. Delić, S. (2012). Sustainable development factors of agriculture in AP of Vojvodina. Novi Sad: The Faculty of Agriculture, University in Novi Sad.

9. Deloitte \& Touche, IIED, ODI, (1999). Sustainable tourism and poverty elimination study, Report to the sector for international development, United Nations Development Programme, office in Podgorica, Podgorica.

10. Demonja, D., Baćac, R. (2012). Contribution to the Development of Rural Tourism 
in Croatia: Proposed Steps for Successful Business. Tourism, 16(4), pg. 134-151, The institute for tourism, Zagreb, Croatia.

11. Đorđević Milošević, S., Milovanović, J. (2012). Sustainable tourism in the function of rural development. Faculty of Applied Ecology - Futura, Singidunum University, Belgrade

12. Đuričić, B. Đ. (2011). The imact of tourism on the development of agrarian production in Zlatibor municipality. Science conference with international participation - Agrobiz 2011, Novi Pazar, Serbia, pg. 115-122.

13. Epler-Wood, M. (2002): Ecotourism: Principles, Practices \& Policies for Sustainability. UNEP, TIES.

14. European Parliamentary Research Service (2012). Rural areas in the European Union, [online], available at: http://epthinktank.eu/2012/11/28/4589/

15. European economic and social committee (2011). Opinion of the European Economic and Social Committee on Rural Development and Employment in the Western Balkans. European economic and social committee, Brussels.

16. Fotiadis, A. (2011). The role of tourism in rural development: the role of tourism in rural development through a comparative analysis of a Greek and a Hungarian rural tourism area. Lambert Academic Publishing, Saarbrücken.

17. Garrod, B., Wornell, R., Youell, R. (2006). Re-conceptualizing rural resources as countryside capital: The case of rural tourism. Journal of Rural Studies, 22(1), pp. 117-28. Institute of Rural Sciences, University of Wales Aberystwyth, Aberystwyth, UK.

18. Goodwin, H. (2009). Reflections on 10 Years of Pro-Poor Tourism. Journal of Policy Research in Tourism, Leisure and Events, 1(1), pp.90-94, Taylor \& Francis Online.

19. Greffe, X. (1994). Is rural tourism a lever for economic and social development? Journal of Sustasinable tourism, 2(1-2), pp. 22-40, Taylor \& Francis Online.

20. International Labour Organization (2011). Rural Policy Briefs, Stimulating Rural Growth, Jobs and Income through Tourism, [online], available at: http://www.ilo. org/employment/units/rural-development/WCMS_161153/lang--en/index.htm

21. Jamieson, W., Goodwin, H., Edmunds, C. (2004). Contribution of Tourism to Poverty Alleviation Pro-Poor Tourism and the Challenge of Measuring Impacts. Transport and Tourism Division, UN ESCAP, Bangkok.

22. Lane, B. (1999). What is Rural Tourism? Its Role in Sustainable Rural Development, Paper presented at Nordisk Bygdeturism Nätverk Conference, Kongsvinger, Norvay, available at: http://www.bygdeturism.com/kongs1.pdf

23. McAreavey, R., McDonagh, J. (2010). Sustainable Rural Tourism: Lesson for Rural Development. Sociologia Ruralis, 51(2), pp. 175-94, Queens University Belfast, Belfast, UK.

24. Meyer, D. (2007). Pro-poor tourism: from leakages to linkages. A conceptual framework for creating linkages between the accommodation sector and 'poor' neighbouring communities. Current Issues in Tourism, 10(6), pp. 558-83, Taylor \& Francis Online. 
25. Milić, B. (2011). Rural development: practicum for local actors. Standing Conference of Towns and Municipalities, Belgrade.

26. Organisation for Economic Co-Operation and Development - OECD (1994). Tourism Strategies and Rural Development, OCDE/GD(94)49, Paris.

27. Petrou, A., Pantziou, E.F., Dimara, E., Skuras D. (2007). Resources and activities complementarities: the role of business networks in the provision of integrated rural tourism. Tourism Geographies, 9(4), pp. 421-40, Taylor \& Francis Online.

28. Petrović, G., Maksimović, M., Karabašević, D. (2017). Strategic positioning of rural tourism on Stara planina, Economics of Agriculture, 64(2), pp. 601-616, Institute of Agricultural economics, Belgrade, Serbia.

29. Rikalović, G., Stojanović Ž., Zorka Z. (2012). New pattern of economic development and employment - model of creative rural industrialization. Proceedings of Matica Srpska for Social Sciences, no. 141, pg. 565-82, Matica srpska, Novi Sad, Serbia.

30. Sattar, S. (2014). Potential of tourism in poverty alleviation and development of Sikkim. IASSI Quarterly Bulletin, 32(3), pp.72-85, Indian Association of Social Science Institutions, New Delhi.

31. Saxena, G., Clark, G., Oliver, T., Ilbery, B. (2007). Conceptualizing integrated rural tourism. Tourism Geographies, 9(4), pp. 347-70, Taylor \& Francis Online.

32. Shtaltovna, A. (2007). Role of Governance in the Diversification of Rural Economy, Analysis of two Ukrainian Cases, M.Sc. thesis, Ghent University of Belgium, Ghent, Belgium.

33. Silva, L., Leal, J. (2015). Rural tourism and national identity building in contemporary Europe: Evidence from Portugal. Journal of Rural Studies, 38, pp. 109-19, Elsevier.

34. Svetozarević, I. (2012). A guide to rural tourism. RARIS, Regional agency for the development of the Eastern Serbia Zaječar.

35. Ševarlić, M.M., Petrović, Z. (2011). The development of countryside tourism in Gornji Milanovac municipality - a model example for the villages in Serbia, Agricultural economics, 58(3), pg. 457-473, Institute of Agricultural economics, Belgrade, Serbia.

36. Škrbić, I., Jegdić, V. Milošević, S., Tomka, D. (2015). Development of Sremski Karlovci wine tourism and integration in the regional tourism offer. Economics of agriculture, LXII(1/2015), pp. 229-244. Institute of Agricultural economics, Belgrade, Serbia.

37. Tolkach, D., Pearlman, M., King, B. (2012). Key Implementation Factors in Pro-poor Tourism. Tourism Recreation Research, 37(1), pp.3-13, Taylor \& Francis Online.

38. Živkov, G. (2010). Sustainable finance of investments before and after the crisis (presentation), Conference on the investments into agro-business sector of Serbia, Novi Sad fair, Novi Sad, May 18, 2010, available at: http://www.agropress.org.rs/ files/finasiranje_poljoprivrede_-_goran_zivkov.pdf

39. Http://www.travinfoindia.com/rural_india_travel.html 


\title{
PRO-POOR TURIZAM U FUNKCIJI RAZVOJA RURALNIH SREDINA
}

\author{
Vaso Jegdič ${ }^{5}$, Iva Škrbićc ${ }^{6}$, Srđan Miloševićc ${ }^{7}$
}

\section{Sažetak}

Predmet istraživanja u ovom radu predstavlja razvoj preduzetništva po principima Propoor turizma u ruralnim destinacijama. Cilj istraživanja jeste projektovanje modela razvoja preduzetništva po principu Pro-poor turizma u ruralnim sredinama Srbije. Primenjen je opšti analitičko-sintetički metod istraživanja, u rasponu od bibliografskospekulativnog, do empirijskog pristupa. Siromaštvo ruralnog stanovništva predstavlja gorući problem mnogih zemalja, pa tako i Srbije. Razvijanje preduzetništva u oblasti turizma ističe se kao jedan od najefikasnijih načina za rešavanje ovog problema. Fokusiranje na pravičnu raspodelu materijalnih i nematerijalnih koristi na području lokalne zajednice podrazumeva usvajanje koncepta razvoja turizma i preduzetništva po principima Pro-poor turizma. To obuhvata razvoj poslovanja u formi mikro, malih i porodičnih preduzeća, razvoj turističkog poslovanja kroz diverzifikaciju proizvoda $i$ aktivnosti koje su tradicionalne za domaćinstva u ruralnim sredinama i uključivanje principa razvoja koji u fokus stavlja interese najsiromašnijih pripadnika lokalne zajednice. Zbog togaje oslanjanje na lokalne resurse uz unapređenje lokalnih kapaciteta i povećanje nivoa participacije lokalnog stanovništva u razvojnim aktivnostima ključ uspeha Pro-poor strategija.

Ključne reči: Pro-poor turizam, ruralni razvoj, ruralna destinacija, Srbija.

5 Vanredni profesor, dr Vaso Jegdić, Univerzitet Edukons, Fakultet za sport i turizam, Radnička 30a, 21000 Novi Sad, Telefon: +381 635506 38, E-mail: vaso.jegdic@tims.edu.rs

6 Docent, dr Iva Škrbić, Univerzitet Edukons, Fakultet za sport i turizam, Radnička 30a, 21000 Novi Sad, Telefon: +381642014 738, E-mail: iva@,tims.edu.rs

7 Docent, dr Srđan Milošević, Univerzitet Edukons, Fakultet za sport i turizam, Radnička 30a, 21000 Novi Sad, Telefon: +381 641800 431, E-mail: $\underline{\text { srdjan.milosevic@tims.edu.rs }}$ 